\title{
OBRÓT DETALICZNY PRODUKTAMI LECZNICZYMI
}

\author{
WSTĘP
}

Z cywilnoprawnym obrotem detalicznym produktami leczniczymi wiąże się ryzyko i niebezpieczeństwo naruszenia zdrowia i życia pacjentów, np. wskutek ich przeterminowania, podrobienia lub niespełniania wymagań jakościowych. Podlega on więc licznym i rygorystycznym ograniczeniom ustawowym, m.in. podmiotowym i przedmiotowym. Stanowi to pierwszą przyczynę wywołującą istotne trudności przy wykładni przepisów, m.in. w obszarze zakresu ograniczeń ustawowych czy skutków ich naruszenia. Ustawodawca, regulując cywilnoprawny obrót detaliczny produktami leczniczymi, nie posługuje się terminologią cywilistyczną nawiązującą do ustawy z dnia 23 kwietnia 1964 r. - Kodeks cywilny ${ }^{1}$ (np. umowa sprzedaży, przedsiębiorca itp.). Zamiast niej sięgnął po terminologię gospodarczą (np. obrót, import, eksport, apteka itp.). Ten brak dostosowania ustawy z dnia 6 września 2001 r. - Prawo farmaceutyczne $^{2}$ do podstawowych konstrukcji i terminologii kodeksu cywilnego stanowi istotny błąd legislacyjny ${ }^{3}$. Jest on także kolejną przyczyną powodującą trudności przy wykładni omawianych przepisów. Problematyka prawa farmaceutycznego znajduje się w kręgu oddziaływania prawa europejskiego, z czym wiąże się konieczność dostosowania do niego prawa polskiego. To z kolei powoduje kolejną trudność w wykładni tych przepisów.

Dr hab. PIOTR ZAKRZEwSKI, prof. KUL - kierownik Katedry Prawa Cywilnego, Instytut Prawa na Wydziale Prawa, Prawa Kanonicznego i Administracji Katolickiego Uniwersytetu Jana Pawła II, Al. Racławickie 14, 20-950 Lublin; e-mail: zakrzew@kul.pl; ORCID: https://orcid.org/0000-00034981-1480.

${ }^{1}$ T.j. Dz.U. z 2020 r., poz. 1740, 2320.

2 T.j. Dz.U. z 2020 r., poz. 944, 1493, 2112; z 2021 r., poz. 97 [dalej: p.f.].

${ }^{3}$ Z. RADWAŃSKI, Prawo cywilne - część ogólna, Warszawa: C.H. Beck 2003, s. 26. 
Celem artykułu jest sformułowanie propozycji wykładni spornych przepisów regulujących obrót detaliczny produktami leczniczymi w odpowiedzi na pojawiające się problemy interpretacyjne. Artykuł obejmuje swoim zakresem także takie zagadnienia, jak pojęcie i przedmiot obrotu, ponieważ stanowią one nieodłączną część tematyki obrotu detalicznego. Jednocześnie są one częścią innej tematyki, mianowicie obrotu hurtowego produktami leczniczymi i weterynaryjnymi oraz wysyłkowej sprzedaży produktów leczniczych. Te ostatnie zagadnienia nie są jednak przedmiotem artykułu.

\section{PRZEDMIOT OBROTU}

\subsection{Produkt leczniczy dopuszczony do obrotu}

Definicję produktu leczniczego zawiera art. 2 pkt 32 p.f. Zgodnie z nią jest to substancja lub mieszanina substancji, przedstawiana jako posiadająca właściwości zapobiegania lub leczenia chorób występujących u ludzi, zwierząt lub podawana $\mathrm{w}$ celu postawienia diagnozy albo w celu przywrócenia, poprawienia lub modyfikacji fizjologicznych funkcji organizmu poprzez działanie farmakologiczne, immunologiczne lub metaboliczne. Z kolei do produktu z pogranicza, czyli produktu, który może jednocześnie odpowiadać wymogom produktu leczniczego oraz wymogom innego rodzaju produktu, np. suplementu diety, kosmetyku, wyrobu medycznego itp., stosuje się ustawę Prawo farmaceutyczne (art. 3a p.f.).

Przedmiotem obrotu mogą być jedynie te produkty lecznicze, które uzyskały pozwolenie na dopuszczenie do obrotu w postaci decyzji administracyjnej wydanej przez uprawniony organ (Prezesa Urzędu Rejestracji Produktów Leczniczych, Wyrobów Medycznych i Produktów Biobójczych - dalej: Prezes Urzędu, oraz Radę Unii i Komisję Europejską) na podstawie właściwej procedury administracyjnej (art. 2 pkt 26 p.f. $)^{4}$.

Pozwolenie w przedmiocie dopuszczenia do obrotu wydane przez Prezesa Urzędu ma charakter terytorialny, tj. uprawnia ono do obrotu produktami leczniczymi jedynie na terytorium Rzeczypospolitej Polskiej (zob. art. 1 ust. 1 pkt 1, 4, art. 2 pkt 26 p.f.). Przedsiębiorca zainteresowany dopuszczeniem produktu leczniczego do obrotu także na terytorium innych niż Polska Państw Członkowskich UE, powinien ubiegać się o pozwolenie wydane przez Prezesa

${ }^{4}$ Zob. uzasadnienie postanowienia Naczelnego Sądu Administracyjnego z dnia 19 sierpnia 2010 r., II GSK 848/10. 
Urzędu w ramach tzw. procedury zdecentralizowanej lub procedury wzajemnego uznania (art. 18a i 19 p.f.). Z pierwszej powinien skorzystać wówczas, gdy produkt leczniczy nie został jeszcze dopuszczony do obrotu w żadnym Państwie Członkowskim, a z drugiej, jeżeli uzyskał już takie pozwolenie w przynajmniej jednym Państwie Członkowskim, a następnie żąda wydania pozwolenia na dopuszczenie do obrotu produktu leczniczego w kolejnym lub kolejnych Państwach Członkowskich.

Pozwolenia na obrót pewnymi produktami leczniczymi ${ }^{5}$ na obszarze wszystkich Państw Członkowskich wydawane są przez Radę Unii i Komisję Europejską ${ }^{6} \mathrm{w}$ ramach tzw. procedury scentralizowanej, prowadzonej przez Europejską Agencję Leków (EMEA) na podstawie rozporządzenia (WE) $\mathrm{Nr}$ 726/2004 Parlamentu Europejskiego i Rady z 31.3.2004 r. ustanawiającego wspólnotowe procedury wydawania pozwoleń dla produktów leczniczych stosowanych u ludzi i do celów weterynaryjnych i nadzoru nad nimi oraz ustanawiającego Europejską Agencję Leków ${ }^{7}$. Produkty lecznicze dopuszczone do obrotu w UE w ramach procedury scentralizowanej wpisywane są do unijnego rejestru produktów leczniczych. Mogą być one przedmiotem obrotu w każdym państwie UE i nie wymagają uzyskiwania innych pozwoleń.

Pozwolenia na dopuszczenie do obrotu nie wymagają ściśle określone $\mathrm{w}$ art. 3 ust. 4 p.f. produkty lecznicze, np. leki recepturowe, apteczne, produkty radiofarmaceutyczne. Nie jest ono także wymagane w razie sprowadzania z zagranicy produktu leczniczego dopuszczonego do obrotu w kraju, z którego jest on sprowadzany ze względu na konieczność ratowania zdrowia lub życia pacjenta (art. 4 p.f.). Zakres obrotu takimi produktami leczniczymi jest ograniczony i sprowadza się do zawarcia pojedynczej umowy sprzedaży produktu leczniczego. Pozwolenia nie wymagają także produkty lecznicze będące przedmiotem importu równoległego, które uzyskały pozwolenie na import równoległy (art. $21 \mathrm{a}$, art. 2 pkt $7 \mathrm{~b}$ p.f.) ${ }^{8}$. Nie jest ono konieczne

\footnotetext{
${ }^{5}$ Wykaz takich produktów leczniczych zawiera załącznik do rozporządzenia (WE) Nr 726/2004 Parlamentu Europejskiego i Rady z 31.3.2004 r. ustanawiającego wspólnotowe procedury wydawania pozwoleń dla produktów leczniczych stosowanych u ludzi i do celów weterynaryjnych i nadzoru nad nimi oraz ustanawiającego Europejską Agencję Leków, Dz. Urz. UE L Nr 136, s. 1 ze zm.

${ }^{6}$ M. Jagielska, A. WojtcZyk, Komentarz do art. 5, [w:] Prawo farmaceutyczne. Komentarz, red. L. Ogiegło, Warszawa: C.H. Beck 2018, art. 3, Nb. 29.

${ }^{7}$ Dz. Urz. UE L Nr 136, s. 1 ze zm., zob. art. 3 ust. 2 p.f.

${ }^{8}$ Szczegółową definicję pojęcia „importu równoległego” podaje art. art. 2 pkt $7 \mathrm{~b}$ p.f. Krytycznie na temat definicji ustawowej importu równoległego - L. OGIEGŁo, Komentarz do art. 2, [w:] Prawo farmaceutyczne. Komentarz, red. L. Ogiegło, art. 2, Nb. 31; M. KONDRAT, Komentarz do art. 2, [w:] Prawo farmaceutyczne. Komentarz, red. M. Kondrat, wyd. 2, Warszawa: Wolters Kluwer Polska 2016, art. 2, Nb. 2.7b.1; R. STANKIEWICZ, Model racjonalizacji dostępu do produktu leczniczego.
} 
w przypadku produktów leczniczych wykorzystywanych w badaniach naukowych i klinicznych, produkcji lub półproduktów (art. 5 p.f.). Przyczyną tego zwolnienia jest znikome ryzyko szkodliwości tych produktów leczniczych oraz potrzeba prowadzenia badań naukowych. Pogląd przeciwny upatruje przyczyny takiej regulacji nie tyle w wykorzystywaniu produktów leczniczych na szeroko rozumiane potrzeby własne wytwórcy, ile w niewielkiej skali obrotu produktami leczniczymi? .

Poza wskazanymi wyjątkami, przedmiotem obrotu nie mogą być produkty lecznicze, które nie są dopuszczone do obrotu na podstawie pozwolenia. Są one rzeczami wyłączonymi z obrotu cywilnoprawnego, a czynności cywilnoprawne, np. umowa sprzedaży mająca je za przedmiot, jest nieważna, tzn. w szczególności nie przenosi ona prawa własności produktów leczniczych na kupującego (art. $58 \S 1$ k.c. w zw. z art. 3 ust. 1 p.f.). Produkt leczniczy wprowadzany do obrotu wbrew ustawie wywołuje także sankcje administracyjne. Jest to podstawą cofnięcia pozwolenia na dopuszczenie do obrotu tego produktu leczniczego (art. 33 ust. 1 pkt 3 p.f.).

Znaczenie pozwolenia na dopuszczenie do obrotu produktu medycznego jest szersze. Według NSA kwalifikuje ono dany produkt jako produkt leczniczy ${ }^{10}$. Produkt leczniczy podlega $z$ urzędu wpisowi do jawnego Rejestru Produktów Leczniczych Dopuszczonych do Obrotu na terytorium Rzeczypospolitej Polskiej (art. 28 p.f.).

Przedstawiona wyżej definicja produktu leczniczego ma m.in. charakter funkcjonalny. Jest nim substancja, którą powinien on zapobiegać lub leczyć choroby występujące u ludzi ${ }^{11}$. Jeżeli zatem dany produkt ma w założeniu spełniać taką funkcję, to nie może on być przedmiotem obrotu bez zezwolenia na dopuszczenie do obrotu, a przed jego wprowadzeniem do obrotu obowiązkiem przedsiębiorcy jest uzyskanie zezwolenia. Jeżeli uprawniony organ odmówi wydania zezwolenia, to wykluczy tym samym skuteczność czynności prawnych, których przedmiotem są produkty lecznicze niedopuszczone

Zagadnienia publicznoprawne, Warszawa: C.H. Beck 2014, s. 383. W kwestii importu równoległego zob. również M. Krekora, Definicje, [w:] M. Krekora, M. Świerczyński, E. Traple, Prawo farmaceutyczne, Warszawa: Wolters Kluwer Polska 2008, s. 30 n.; D. BiAdun, Obrót produktami leczniczymi w'świetle orzecznictwa sadowego, Warszawa: Wolters Kluwer Polska 2012, s. 76 n.; M. RoszAK, Handel równolegly produktami leczniczymi w prawie unijnym. Granice swobody przepływu towarów na rynku farmaceutycznym, Warszawa: Wolters Kluwer Polska 2014, s. 168.

${ }^{9}$ M. OżóG, System handlu produktem leczniczym i produktami pokrewnymi. Problematyka prawna, Warszawa: LexisNexis 2009, s. 205; M. JAGIELSKA, A. WoJTCZYK, Komentarz do art. 5, Nb. 1.

${ }^{10}$ Wyrok Naczelnego Sądu Administracyjnego z dnia 29 marca 2012 r., II GSK 152/11.

${ }^{11}$ Zob. uzasadnienie wyroku Wojewódzkiego Sądu Administracyjnego siedziba w Warszawie z dnia 3 lutego 2009 r., V SA/Wa 2207/08. 
do obrotu ze względu na sprzeczność z ustawą (art. 58 § 1 k.c.). Obrót nimi rodzi także skutki administracyjnoprawne w postaci cofnięcia zezwolenia na prowadzenie m.in. apteki ogólnodostępnej (zob. art. 81 ust. 1 pkt 1, art. 103 ust. 1 pkt 1 p.f.).

Z punktu widzenia obrotu produktami leczniczymi ważne jest zwrócenie uwagi, że mają one postać przedmiotów materialnych lub cieczy w postaci zamkniętej, czyli są rzeczami ruchomymi w rozumieniu art. 46 k.c. (zob. art. 155 n. k.c.). Świadczenie, które ma za przedmiot takie rzeczy, jest świadczeniem oznaczonym co do gatunku, czyli oznaczonym według cech właściwych dla większej grupy rzeczy, z jakiej się je wydziela za pomocą liczby, miary wagi ${ }^{12}$. Jest to także świadczenie podzielne.

Odnośnie do pozwolenia na wprowadzenie produktu leczniczego do obrotu należy zauważyć, że istnienie takiego zezwolenia nie wyłącza bezprawności czynu zabronionego, polegającego na zastosowaniu produktu leczniczego, który doprowadzi do wywołania szkody. W szczególności podstawą takiej odpowiedzialności odszkodowawczej mogą być przepisy o odpowiedzialności za produkt niebezpieczny (art. 35a p.f. w zw. z art. $416,449^{1}$ k.c.).

\subsection{Wymagania jakościowe i zakaz obrotu produktami leczniczymi przeterminowanymi}

Ponieważ produkty lecznicze są rzeczami oznaczonymi co do gatunku, to powstaje pytanie, jaką powinny mieć jakość, jeżeli stanowią przedmiot świadczenia. Wymagania jakościowe produktów leczniczych określa Farmakopea Europejska lub jej tłumaczenie na język polski zawarte w Farmakopei Polskiej, wydawane przez Urząd Rejestracji Leków, Wyrobów Medycznych i Produktów Biobójczych, będąca urzędowym spisem produktów leczniczych dopuszczonych do obrotu (art. 23 ust. 2, art. 25 ust. 1 p.f., art. 357 k.c.) ${ }^{13}$. Oznacza to, że produkty lecznicze mają odpowiadać wspomnianym wymaganiom jakościowym i nie mogą mieć średniej jakości (por. 357 k.c.).

Wyłączone z obrotu są produkty lecznicze, których termin ważności upłynął lub które nie odpowiadają wymaganiom jakościowym (art. 66, 67 ust. 1 p.f.). Umowa, która miałaby za przedmiot takie produkty lecznicze, byłaby nieważna (art. art. 66 i 67 ust. 1 p.f. w zw. z art. $58 \S 1$ k.c.). Z odmiennym przypadkiem mielibyśmy do czynienia, gdyby treść umowy sprzedaży dotyczyła produktów

\footnotetext{
${ }^{12}$ Zob. zamiast wielu W. CZAChÓRSKI, A. BrZOZOwsKi, M. SAFJAN, E. SKOwroŃSKA-BociAn, Zobowiazania. Zarys wyktadu, Warszawa: Wolters Kluwer Polska 2009, s. 68.

${ }^{13}$ Zob. A. BRzOZOwSKI, Komentarz do art. 357, [w:] Kodeks cywilny. Komentarz do artykułów $1-449^{11}$, red. K. Pietrzykowski, t. I, Warszawa: C.H. Beck 2008, s. 941.
} 
leczniczych z aktualnym terminem ważności oraz odpowiadających wymaganiom jakościowym, ale sprzedawca dostarczyłby produkty lecznicze nieodpowiadające treści umowy. Skutkowałoby to odpowiedzialnością z tytułu rękojmi za wady fizyczne rzeczy sprzedanej oraz odpowiedzialnością odszkodowawczą z tytułu nienależytego wykonania ważnie zaciągniętego zobowiązania ze względu na brak należytej jakości przedmiotu świadczenia (art. 556, $556^{1} \S 1$ pkt 1 , art. 471 k.c.).

Produkt leczniczy, który nie odpowiada wymaganiom jakościowym lub którego termin ważności upłynął, może być także uznany za produkt niebezpieczny w rozumieniu art. $449^{1} \S 3$ k.c. Wprowadzenie przez producenta do obrotu takiego produktu w zakresie działalności swojego przedsiębiorstwa może rodzić odpowiedzialność odszkodowawczą za wyrządzoną komukolwiek przez niebezpieczny produkt szkodę. To samo dotyczy wytwórcy materiału, surowca albo części składowej produktu niebezpiecznego, osoby podającej się za producenta i importera (art. $449^{5}$ § 1-2 k.c.).

Ze względu na szerokie rozumienie pojęcia obrotu produktami leczniczymi - niezależnie od powyższych skutków cywilnoprawnych - wydanie produktów leczniczych, które nie spełniają wymagań jakościowych i terminu ważności, pociąga zawsze negatywne konsekwencje administracyjnoprawne w postaci decyzji Głównego Inspektora Farmaceutycznego o zakazie wprowadzenia lub o wycofaniu $z$ obrotu produktu leczniczego (art. 122 ust. 1 p.f.), o zniszczeniu produktu leczniczego (art. 122 ust. 1 pkt 1, art. 67 ust. 2 p.f.) lub kary pieniężnej na rzecz Skarbu Państwa (art. 129c ust. 1 p.f.). Może także skutkować cofnięciem przedsiębiorcy zezwolenia na prowadzenie m.in. apteki (zob. art. 37 ap ust. 1 pkt 3 , art. 103 ust. 2 pkt 1 p.f.) ${ }^{14}$.

Jeżeli chodzi o to, która ze stron sprzedaży odpowiada za wystąpienie ryzyka w postaci upływu terminu ważności produktu leczniczego lub pogorszenia się jego jakości po zawarciu umowy, a przed jej wykonaniem, to obowiązuje tu zasada ogólna. Zgodnie $\mathrm{z}$ nią $\mathrm{z}$ chwilą wydania rzeczy przechodzi na kupującego m.in. ryzyko przypadkowej utraty i uszkodzenia rzeczy (art. 548 k.c.). Rozwiązanie to należy także stosować wobec innych niż sprzedaż umów, np. umowy składu konsygnacyjnego. Do niej należy się także odwołać przy rozstrzyganiu, na której ze stron ciąży ustawowy obowiązek w postaci pokrycia kosztów zniszczenia produktu leczniczego, którego termin ważności upłynął. Tym samym kryterium powinien się kierować organ, rozstrzygając

${ }^{14}$ Zob. B. NOWAK-CHRZĄSZCZ, Komentarz do art. 66, 67, [w:] Prawo farmaceutyczne. Komentarz, red. W.L. Olszewski, Warszawa: Wolters Kluwer Polska 2016, art. 66, nb. 5, art. 67, Nb. 8. 
o kosztach zniszczenia produktu leczniczego, który nie odpowiada wymaganiom jakościowym (art. 67 ust. 3 p.f.).

\subsection{Nazwa i opakowanie produktu leczniczego dopuszczonego do obrotu}

Produkt leczniczy uczestniczy w obrocie pod nazwą, którą może być nazwa własna. Przyjmuje ona najczęściej postać wyrazu, który może stanowić znak towarowy (art. 120 ust. 1 u.w.p. ${ }^{15}$ ). Nazwa produktu leczniczego jest zasadniczo dowolna $z$ pewnymi ograniczeniami. Nie może ona jednak stwarzać niebezpieczeństwa pomyłki z tzw. nazwą powszechnie stosowaną, nazwą naukową, nazwą innego produktu medycznego opatrzonego chronionym znakiem towarowym lub nazwą (firmą) przedsiębiorcy, który uzyskał pozwolenie na dopuszczenie do obrotu produktu leczniczego (art. 2 pkt 14, 24 p.f.). Wykluczone jest m.in. posłużenie się tzw. nazwą powszechnie stosowaną, którą jest międzynarodowa unikalna nazwa niezastrzeżona (International Non-Proprietary Names) nadawana przez Światową Organizację Zdrowia. Odwołuje się ona do substancji farmaceutycznej lub aktywnych składników farmaceutycznych (art. 2 pkt 15 p.f.). Należy ona do domeny publicznej i każdy może z niej nieodpłatnie korzystać ${ }^{16}$. Nazwa produktu leczniczego stwarzająca możliwość pomyłki z tzw. nazwą powszechnie stosowaną nie może być także przedmiotem znaku towarowego (art. 2 pkt 14 p.f. w zw. z art. $129^{1}$ ust. 1 pkt 7 u.w.p.).

Produkt leczniczy będący lekiem gotowym występuje w obrocie pod określoną nazwą i w określonym opakowaniu (art. 2 pkt 11 p.f.). Przyjąć trzeba, że chodzi tu o opakowanie zewnętrzne, w którym znajduje się opakowanie bezpośrednie, czyli mające bezpośredni kontakt z produktem leczniczym (art. 2 pkt 20-21, art. p.f.). W celu ochrony pacjentów niewidomych i słabowidzących nazwę produktu medycznego umieszcza się na opakowaniu także w systemie Braille'a. Na opakowaniu znajduje się oznakowanie produktu leczniczego, które zawiera informacje o produkcie leczniczym, w tym m.in.: nazwę produktu leczniczego i nazwę powszechnie stosowaną substancji czynnej, moc produktu leczniczego, określenie postaci farmaceutycznej, informację, czy produkt jest przeznaczony dla niemowląt, dzieci lub dorosłych itd. (art. 2 pkt 22, art. 26 ust. 2 p.f. w zw. z $\S 3$ i n. rozporządzenia Ministerstwa Zdrowia z 20.2.2009 r. w sprawie wymagań dotyczących oznakowania opakowań produktu leczniczego i treści ulotki) ${ }^{17}$. Do produktu

\footnotetext{
${ }^{15}$ Ustawa z dnia 30 czerwca 2000 r. - Prawo własności przemysłowej, t.j. Dz.U. z 2021 r., poz. 324.

${ }^{16} \mathrm{https} / / /$ www.who.int/medicines/services/inn/en/ [dostęp: 8.05.2019].

17 T.j. Dz.U. z 2015 r., poz. 1109.
} 
leczniczego należy dołączyć ulotkę, która zawiera m.in. dane pozwalające zidentyfikować produkt leczniczy, w tym m.in. jego nazwę, wskazania do stosowania, informacje niezbędne przed stosowaniem produktu leczniczego (§ 5 n. rozporządzenia Ministerstwa Zdrowia z 20.2.2009 r. w sprawie wymagań dotyczących oznakowania opakowań produktu leczniczego i treści ulotki). Niedołączenie ulotki stanowi wadę fizyczną rzeczy sprzedanej (art. 556 ${ }^{1} \S 1$ pkt 4 k.c.). Skutkować także może odpowiedzialnością z tytułu nienależytego wykonania zobowiązania (art. 471 k.c.). Nazwa produktu leczniczego, jego opakowanie, oznakowanie, ulotka podlegają zatwierdzeniu w wydanym pozwoleniu o dopuszczeniu do obrotu (art. 23 ust. 2 p.f.).

\section{OBRÓT PRODUKTAMI LECZNICZYMI}

\subsection{Cywilnoprawny charakter obrotu produktami leczniczymi}

Posłużenie się w prawie farmaceutycznym pojęciami, które nie nawiązują do terminologii kodeksu cywilnego, takimi jak np. „obrót produktami leczniczymi” czy „świadczenie usług farmaceutycznych”, oraz występowanie licznych ograniczeń ustawowych $\mathrm{w}$ zakresie obrotu produktami leczniczymi, dały asumpt do pojawienia się rozbieżnych poglądów $\mathrm{w}$ przedmiocie cywilnoprawnego ${ }^{18}$ oraz administracyjnoprawnego ${ }^{19}$ charakteru obrotu produktami leczniczymi.

Stanowisko opowiadające się za cywilnoprawnym charakterem obrotu produktami leczniczymi oznaczałoby, że pomimo administracyjnoprawnych ram reglamentujących ten obrót, podmioty w nim uczestniczące zachowywałyby autonomiczną względem siebie pozycję prawną, a sam obrót następowałby na podstawie czynności cywilnoprawnych, takich jak umowy sprzedaży, dostawy, dzieła, komisu itp. Stanowisko przeciwne, zakładające administracyjnoprawny charakter obrotu, musiałoby oznaczać podrzędność jednej strony. Sam obrót następowałby na podstawie instytucji administracyjnoprawnych wynikających z ustawy Prawo farmaceutyczne, a jedynie w niewielkim stopniu byłby „wsparty” przez czynności cywilnoprawne. Argumentacja zwolenników tego ostatniego stanowiska zakłada, że obrót i wydanie

${ }^{18}$ M. JAgielska, A. WojtcZyK, Komentarz do art. 65, [w:] Prawo farmaceutyczne. Komentarz, red. L. Ogiegło, art. 65, Nb. 1.

${ }^{19}$ Zob. R.J. KRUSZYŃSKI, Obrót produktem leczniczym w ramach rynku wewnętrznego, „Przegląd Ustawodawstwa Gospodarczego" 2010, nr 7, s. 16 n.; R. STANKIEWICZ, Obrót produktami leczniczymi, [w:] Instytucje rynku farmaceutycznego, red. R. Stankiewicz, Warszawa: Wolters Kluwer Polska 2016, s. 348 n. 
produktów leczniczych następuje na podstawie pozbawionego cywilnoprawnego charakteru aktu świadczenia w postaci usługi farmaceutycznej (por. art. 86 ust. 1 p.f.). Wprawdzie zwracają oni uwagę, że obrót ten jest powiązany $\mathrm{z}$ umową cywilnoprawną, ale jej znaczenie wyraźnie marginalizują ${ }^{20}$. Na rzecz tego stanowiska przemawiać ma także ich zdaniem silne ograniczenie obrotu za pomocą instrumentów administracyjnoprawnych, które w istocie wyklucza występowanie tu wolności umów (art. $353^{1}$ k.c.). Strony obrotu detalicznego, np. apteki ogólnodostępne mają obowiązek zaspokajania leczniczych potrzeb ludności. Tak samo jest w obrocie hurtowym, który stanowi punkt wyjścia do późniejszego zaspokajania wspomnianych potrzeb ludności. Nie występuje także swoboda wyboru strony oraz treści zawieranych umów ${ }^{21}$.

Przechodząc do zajęcia stanowiska w tym sporze, należy zauważyć, że przepisy są sformułowane w sposób niejednoznaczny. W myśl art. 86 p.f. apteki świadczą usługi farmaceutyczne. Mogłoby to prowadzić do wniosku, że apteki nie sprzedają produktów leczniczych obywatelom. Jest to jednak wniosek przedwczesny, ponieważ $w$ pozostałych przepisach dotyczących obrotu produktami leczniczymi jest jednoznacznie mowa o ich sprzedaży, sprzedaży wysyłkowej, zbyciu, zakupie czy nieważności czynności prawnej (art. 24 ust. 3 pkt 5, art. $37 \mathrm{aw}$, art. 88 ust. 5 pkt 5 i 5a, art. 70 ust. 5, art. 73a ust. 1 , art. 103 ust. 2 pkt 7 p.f.). Ustawodawca wprawdzie niekonsekwentnie posługuje się językiem prawnym w ustawie Prawo farmaceutyczne, ale szersze spojrzenie na treść przepisów pozwala jednoznacznie przyjąć wniosek o braku podstaw do kwestionowania w świetle wykładni językowej cywilnoprawnego charakteru obrotu produktami leczniczymi.

$\mathrm{Z}$ art. 87 ust. 2 pkt 1 p.f. wynika, że apteki ogólnodostępne przeznaczone są do zaopatrywania ludności w produkty lecznicze, leki apteczne itp. Mogłoby to sugerować istnienie publicznoprawnego obowiązku dostarczania ludności przez apteki produktów leczniczych itp. Jest to jednak wniosek nietrafny, ponieważ celem art. 87 ust. 1 p.f. jest klasyfikacja aptek z punktu widzenia adresatów ich działalności, a nie regulowanie obrotu produktami leczniczymi między apteką ogólnodostępną a pacjentem. Taki obrót dokonuje się na podstawie umowy cywilnoprawnej, jak sprzedaż. Wspomniany art. 87 ust. 1 p.f. nie stanowi więc argumentu na rzecz publicznoprawnego charakteru obrotu produktami leczniczymi.

${ }^{20}$ Zob. R.J. KRUSZYŃski, Obrót produktem leczniczym, s. 16 n.; R. Stankiewicz, Obrót produktami leczniczymi, s. $348 \mathrm{n}$.

${ }^{21}$ R. Stankiewicz, Obrót produktami leczniczymi, s. 348 n.; TENŻE, Model, s. 348 n. 
Podobnie należy ocenić znaczenie art. 94 ust. 1 p.f., który przewiduje, że rozkład godzin pracy aptek ogólnodostępnych powinien być dostosowany do potrzeb ludności i zapewniać dostępność świadczeń również w porze nocnej, niedzielę, święta i inne dni wolne. Reguluje on czas i sposób organizacji sprzedaży produktów leczniczych przez przedsiębiorcę ze względu na ich szczególne znaczenie dla życia i zdrowia ludności. Nie wynika jednak z niego obowiązek zawierania przez aptekę ogólnodostępną umów sprzedaży z osobami. To samo można powiedzieć o art. 95 ust. 1 p.f., który wymaga, aby apteki ogólnodostępne posiadały produkty lecznicze i wyroby medyczne w ilości i asortymencie koniecznym do zaspokojenia potrzeb zdrowotnych ludności.

Jeżeli apteka ogólnodostępna nie zaspokaja potrzeb leczniczych pacjentów w sposób uporczywy w zakresie wydawania produktów leczniczych, np. dlatego, że ma niewłaściwy rozkład godzin pracy lub brak wystarczającej ilości produktów leczniczych, to sankcja z tego powodu ma charakter administracyjny i polega na obowiązkowym cofnięciu przez Wojewódzkiego Inspektora Farmaceutycznego zezwolenia na prowadzenie apteki ogólnodostępnej (art. 103 ust. 2 pkt 3 p.f.).

Ustawa Prawo farmaceutyczne nie formułuje więc expressis verbis obowiązku zawierania np. umów sprzedaży produktów leczniczych w ramach obrotu detalicznego między apteką ogólnodostępną a kupującym, jak czyni to przykładowo art. 7 ustawy z dnia 10 kwietnia Prawo energetyczne ${ }^{22}$. Określa on także treść zawieranej umowy o przyłączenie do sieci.

$\mathrm{Z}$ art. 68 ust. 1 p.f. wynika m.in., że obrót detaliczny produktami leczniczymi prowadzony jest w aptekach ogólnodostępnych. Występuje tu więc ograniczenie wolności umów, polegające na braku swobody wyboru kontrahenta przez kupującego, którym może być zasadniczo tylko przedsiębiorca prowadzący aptekę (zob. art. 68 ust. 2, art. 70 ust. 1 i art. 71 ust. 1 p.f.). Kupujący nie ma jednak obowiązku kontraktowania $\mathrm{z}$ konkretnym przedsiębiorcą prowadzącym aptekę ogólnodostępną, ale może zawrzeć umowę $\mathrm{z}$ dowolnym przedsiębiorcą, który ją prowadzi. W rozwiązaniu tym występuje wprawdzie ograniczenie wolności umów, ponieważ umowę wolno zawrzeć tylko z przedsiębiorcą, który uzyskał pozwolenie na prowadzenie apteki ogólnodostępnej, ale kupujący zachowuje swobodę wyboru, z którym $\mathrm{z}$ takich przedsiębiorców konkretnie zawrzeć umowę ${ }^{23}$. Ograniczenie wolności

${ }^{22}$ T.j. Dz.U. z 2018 r., poz. 755, 650, 685, 771, 1000, 1356, 1629, 1637, 2348; z 2019 r., poz. $42,125,492$.

${ }^{23}$ Takie samo podmiotowe ograniczenie wolności wyboru kontrahenta występuje w obrocie hurtowym produktami leczniczymi. Zgodnie z art. 72 ust. 1 p.f. obrót hurtowy produktami leczni- 
umów ma więc tu wąski zakres, który nie przekreśla cywilnoprawnego charakteru obrotu produktami leczniczymi ${ }^{24}$.

W przypadku obrotu detalicznego nie ciąży na przedsiębiorcy prowadzącym aptekę publicznoprawny obowiązek kontraktowania rozumiany $\mathrm{w}$ ten sposób, że potencjalny nabywca produktu leczniczego będzie mógł domagać się zawarcia umowy w drodze przymusowej ze względu na swoją nadrzędną pozycję (por. art. 64 k.c. w zw. z 1047 k.p.c. ${ }^{25}$ ). Zasadniczo więc umowa sprzedaży dotycząca produktu leczniczego, pomijając istnienie warunków ustawowych, dochodzi najczęściej do skutku w drodze oferty i jej przyjęcia, jeżeli strony osiągną konsensus co do przedmiotu i ceny. W obrocie detalicznym z ofertą sprzedaży produktu leczniczego występuje przedsiębiorca prowadzący aptekę ogólnodostępną, ponieważ zgodnie z art. 543 k.c. wystawienie rzeczy w miejscu sprzedaży na widok publiczny uważa się za ofertę sprzedaży.

\subsection{Pojęcie i rodzaje obrotu produktami leczniczymi}

Pojęcie obrotu produktami leczniczymi nie jest zdefiniowane w przepisach. W piśmiennictwie zwolennicy cywilnoprawnego charakteru takiego obrotu przyjmują, że polega on na przeniesieniu własności produktu leczniczego na mocy czynności prawnej ${ }^{26}$. Jest to trafny pogląd, z tym że z uwagi na art. 72 ust. 3 p.f. wymaga on doprecyzowania, mianowicie pojęcie to obejmuje także czynności faktyczne pozostające w związku z czynnościami prawnymi, np. wydanie produktu leczniczego polegające na przeniesieniu posiadania, odebranie (art. 67 ust. 3 p.f.). Oznacza to, że ograniczenia ustawowe dotyczące obrotu produktami leczniczymi obejmują czynności od zawarcia umowy do jej wykonania.

czymi mogą prowadzić wyłącznie przedsiębiorcy, którzy uzyskali zezwolenie na prowadzenie hurtowni farmaceutycznych. Ich kontrahentami występującymi np. jako sprzedający lub kupujący mogą być wytwórcy, importerzy produktów leczniczych, inni przedsiębiorcy zajmujący się obrotem hurtowym, apteki, zakłady lecznicze dla zwierząt i inne upoważnione podmioty.

${ }^{24}$ Zob. na temat takich ograniczeń: R. LONGCHAMPS DE BERIER, Zobowiązania, Lwów: Księgarnia Wydaw. Gubrynowicz i Syn 1938, s. 159; Z. RADWAŃSKI, Zobowiązania - część ogólna, Warszawa: C.H. Beck 2003, s. 136-138; A. ŁuPSZAK-ZAJĄC, Realizacja roszczenia o zawarcie umowy, Warszawa: C.H. Beck 2005, s. 66 n.

${ }^{25}$ Ustawa z dnia 17 listopada 1964 r. - Kodeks postępowania cywilnego, t.j. Dz.U. z 2020 r., poz. $1575,1578,2320$; z 2021 r., poz. 11.

${ }^{26}$ Zob. M. ŚWIERCZYŃSKI, Obrót produktami leczniczymi oraz wymagania dotycząe podmiotów prowadzacych obrót, [w:] M. KREKORA, M. ŚwIERCZYŃSKI, E. TRAPLE, Prawo farmaceutyczne, s. 392; M. JagielsKa, A. WoJTCZYK, Komentarz do art. 65, Nb. 1. 
Od tak rozumianego pojęcia obrotu produktami leczniczymi zachodzą wyjątki. Obrót na potrzeby rezerw strategicznych nie jest ograniczony podmiotowo. Nabywcą jest wówczas Agencja Rezerw Materiałowych. Nie są z nim związane także obowiązki sprawozdawcze. Obrotem przywiezionymi z zagranicy w celach reklamowych próbkami produktu leczniczego może się zajmować tylko przedsiębiorca, który ubiega się lub uzyskał pozwolenie na dopuszczenie do obrotu produktu leczniczego (art. 65 ust. 1a, 1b, 2 p.f.) ${ }^{27}$. W obu tych przypadkach nie występują także ograniczenia związane z tzw. kanałami dystrybucji czy miejscem dokonywania transakcji. Natomiast aktualne są wymagania dotyczące zbywania produktów leczniczych w granicach ich terminów ważności i odpowiedniej jakości (art. 66, 67, ust. 1 p.f.).

Warunki obrotu niektórymi produktami leczniczymi zostały z kolei zawężone przez konieczność poddania ich przed wprowadzeniem do obrotu kontroli seryjnej wstępnej, wykonywanej przez instytuty badawcze oraz laboratoria kontroli jakości leków (art. 65 ust. 4-9 p.f.). Zbywanie takich produktów leczniczych bez wymaganej kontroli wstępnej jest nieważne (art. 58 § 1 k.c.), a także może wywołać sankcje administracyjnoprawne (art. 103 ust. 2 pkt 1 p.f.).

Skutkiem naruszenia licznych ograniczeń związanych z obrotem produktami leczniczymi jest nieważność umów; dalszą tego konsekwencją - obowiązek zwrotu spełnionych świadczeń wzajemnych, tj. produktów leczniczych z jednej i ceny z drugiej strony (art. 410 w zw. z art. 405 i 406 k.c.).

\section{OBRÓT DETALICZNY}

\subsection{Przedsiębiorcy uprawnieni do dokonywania obrotu detalicznego i zamknięty katalog czynności składających się na obrót detaliczny}

$\mathrm{Z}$ art. 68 ust. 1 , art. 70 ust. 1 , art. 71 ust. $1 \mathrm{w}$ zw. $\mathrm{z}$ art. 65 ust. 1 p.f. wynika, że obrót detaliczny produktami leczniczymi i świadczenie usług farmaceutycznych podlega ograniczeniom podmiotowym, tzn. że mogą go prowadzić apteki ogólnodostępne, punkty apteczne i placówki obrotu pozaaptecznego. Inne podmioty nie mogą się tym zajmować pod rygorem wystąpienia sankcji cywilnych, administracyjnych i karnych. Dotyczy to także aptek szpitalnych i zakładowych, których celem jest jedynie zaopatrywanie w produkty lecznicze podmiotów, przy których zostały one utworzone (art. 87 p.f.).

${ }^{27}$ Ustawa z dnia 29 października 2010 r. o rezerwach strategicznych, t.j. Dz.U. z 2017 r., poz. 1846. 
Pojęcia apteki ogólnodostępnej, punktu aptecznego oraz placówki obrotu pozaaptecznego zostały użyte $\mathrm{w}$ przywołanych przepisach $\mathrm{w}$ znaczeniu funkcjonalnym, jako odzwierciedlające aktywności przedsiębiorcy polegające na prowadzeniu przedsiębiorstwa zajmującego się obrotem detalicznym produktami leczniczymi i świadczeniem usług farmaceutycznych (zob. art. 86 ust. 1 p.f.). Takim przedsiębiorcą może być osoba fizyczna, spółka cywilna, osoba prawna oraz spółka prawna niemająca osobowości prawnej (zob. art. 70 ust. 2 p.f., zob. art. $43^{1}$ k.c., art. 4 i 3 u.p.p. ${ }^{28}$ ). Prowadzenie apteki ogólnodostępnej oraz punktu farmaceutycznego wymaga pozwolenia wydanego przez wojewódzkiego inspektora farmaceutycznego (art. 99-100, art. 70 ust. $4 \mathrm{w} \mathrm{zW}$. z art. 99 ust. 2 i 3, art. 100 ust. 1-3 p.f.). Do prowadzenia placówki obrotu pozaaptecznego nie jest wymagane zezwolenie, ale może ją prowadzić jedynie farmaceuta, technik farmaceutyczny i absolwent kursu II stopnia z zakresu towaroznawstwa zielarskiego lub przedsiębiorca zatrudniający wymienione osoby w charakterze kierownika tych placówek (art. 71 ust. 2 p.f.). Prowadzenie apteki ogólnodostępnej i punktu aptecznego wymaga ponadto spełnienia dalej idących wymagań w zakresie jej personelu, warunków lokalowych, godzin pracy itd., np. kierownikiem takich jednostek może być jedynie farmaceuta (zob. art. 88, 70 ust. 2 b, art. 71 ust. 2, 3 pkt 3-4, art. 97 p.f.).

Apteka $\mathrm{w}$ znaczeniu funkcjonalnym ma także status placówki ochrony zdrowia publicznego (art. 86 ust. 1 p.f.). Oznacza to, że przedsiębiorca w prowadzonej działalności nie może kierować się jedynie chęcią osiągania zysku, ale musi realizować cel publicznoprawny związany z ochroną zdrowia obywateli. Wynika z niego obowiązek uczciwego, rzetelnego i obiektywnego działania na rzecz pacjentów, oferowania takich produktów leczniczych i w sposób, który pozwoli na realizację wymienionego celu, tj. w odpowiednich godzinach, w porze nocnej, posiadania produktów leczniczych i wyrobów medycznych w ilości i asortymencie niezbędnym do zaspokajania potrzeb zdrowotnych ludności (zob. m.in. art. 94 ust. 1, art. 95 ust. 1-1a p.f.), a także udzielania informacji bez kierowania się chęcią osiągnięcia najwyższych zysków czy zwiększenia obrotu itp., oferowania szerokiej palety produktów leczniczych, a nie jedynie tych, na których przedsiębiorca osiąga najwyższą marżę, czy mających najwyższą cenę a standardowe właściwości lecznicze oraz zakaz reklamy. Zaniechanie realizacji celów publicznych skutkować może sankcją w postaci cofnięcia zezwolenia (art. 103 ust. 2 pkt 1, 3 p.f.). Przedsiębiorca ze względu na treść art. 86 ust. 1 p.f. nie jest natomiast pozbawiony swobody ustalania ceny (marży) produktów leczniczych

\footnotetext{
${ }^{28}$ Ustawa z dnia 6 marca 2018 r. - Prawo przedsiębiorców, Dz.U. z 2018 r., poz. 646.
} 
i usług farmaceutycznych. Nie ma również obowiązku sprzedawania leków bez marży lub z minimalną marżą (art. $353^{1}$ k.c.). Zarobkowanie, choć mające wspomniane ograniczenia, jest zasadniczym celem działalności przedsiębiorcy także prowadzącego aptekę ogólnodostępną.

Termin „apteka” występuje także w innym znaczeniu. Jest m.in. chronioną (wyłączną) nazwą, służącą oznaczeniu miejsca prowadzonej przez przedsiębiorcę działalności (art. 86 ust. 2 p.f.). Stanowi on również człon nazwy (firmy) przedsiębiorcy składającej się z wyrazu „apteka” i innego wyrazu (art. 100 ust. 1, art. 102 pkt 4 p.f.). Jest więc nazwą rodzajową, wskazującą pewnych przedsiębiorców i jednocześnie przedmiot prowadzonego przedsiębiorstwa. Przedsiębiorca może się posługiwać tak zbudowaną nazwą (firmą), gdy została ona uwzględniona w treści zezwolenia, a jeżeli przedsiębiorca zamierza nadać nazwę aptece już po uzyskaniu zezwolenia, to winien wystąpić z wnioskiem o dokonanie stosownej zmiany. Ograniczenia dotyczące nazewnictwa nie istnieją w przypadku prowadzenia punktu aptecznego czy placówki obrotu pozaaptecznego. Wydaje się jednak, że posługiwanie się nazwą punktu aptecznego zarówno na oznaczenie miejsca działalności, jak i nazwy (firmy) przedsiębiorcy, który nie uzyskał stosownego zezwolenia, stanowiłoby czyn nieuczciwej konkurencji. To samo zasadniczo dotyczy przedsiębiorcy, który używa nazwy placówki obrotu pozaaptecznego, choć nie prowadzi sprzedaży produktów leczniczych wydawanych bez recepty.

Reklama apteki ogólnodostępnej, punktu aptecznego oraz placówek obrotu pozaaptecznego odnosząca się do produktów leczniczych lub wyrobów medycznych rozumianych w powyższym znaczeniu jest zakazana, z wyjątkiem informacji o godzinach pracy apteki lub punktu aptecznego (art. 94a ust. 1-2 w zw. z art. 52 p.f.). Niedozwolona reklama może m.in. przyjąć postać programu lojalnościowego, polegającego na ,informowaniu i zachęcaniu do zakupu produktów leczniczych lub wyrobów medycznych w danej aptece poprzez «program» kierowany do klientów, który dla jego uczestników przewiduje określone bonusy, upusty, rabaty przy nabyciu towarów, co ma na celu zwiększenie ich sprzedaży"29.

${ }^{29}$ Wyrok Wojewódzkiego Sądu Administracyjnego w Warszawie z 24.01.2013 r., VI SA/Wa 1908/12, LEX nr 1369079; wyrok Naczelnego Sądu Administracyjnego z 11.03.2015 r., II GSK 168/14, LEX nr 1774885; zob. także wyrok Naczelnego Sądu Administracyjnego z 24.09.2014 r., II GSK 1102/13, LEX nr 1572591; wyrok Wojewódzkiego Sądu Administracyjnego w Warszawie z 11.03.2015 r., VI SA/Wa 2639/14, LEX nr 1817355 


\subsection{Zamknięty katalog czynności przedsiębiorców uprawnionych do dokonywania obrotu detalicznego}

W najszerszym ujęciu obrót detaliczny produktów leczniczych i świadczenie usług farmaceutycznych mogą podejmować apteki ogólnodostępne. W piśmiennictwie i orzecznictwie występuje spór co do zakresu czynności (usług) z ochrony zdrowia, które może realizować taka apteka. Według stanowiska pierwszego są one zamieszczone w katalogu zamkniętym, co wyklucza dokonywanie innych czynności i usług poza przewidzianymi w przepisach. Opiera się ono na literalnej wykładni art. 86 ust. 1-2b, 5, 8-9, art. 87 ust. 2 p.f. ${ }^{30}$ Te czynności dzielą się na podstawowe, takie jak wydawanie produktów leczniczych i wyrobów medycznych, udzielanie o nich informacji, sporządzanie leków recepturowych i aptecznych, oraz pozostałe, w szczególności sprzedaż innych produktów wymienionych w art. 75 ust. $5 \mathrm{w}$ zw. z art. 86 ust. 8 p.f., a także inne czynności określone w dotychczas niewydanym przez ministra zdrowia rozporządzeniu (art. 86 ust. 9 p.f.). NSA odnosząc się do tego podziału, zwrócił uwagę, że: „Podstawową działalnością apteki jest świadczenie przez uprawnione osoby usług farmaceutycznych, a sprzedaż produktów wymienionych $\mathrm{w}$ art. 72 ust. 5 Prawa farmaceutycznego może być prowadzona tylko pod warunkiem, że ich przechowywanie i sprzedaż nie będą przeszkadzać podstawowej działalności apteki" ${ }^{31}$. Oznacza to także wymóg oddzielnego magazynowania takich produktów ${ }^{32}$. Nie jest jasne, czy wszystkie czynności mieszczące się w grupie czynności podstawowych mają charakter obligatoryjny, czyli że apteka musi je dokonywać, np. sporządzać leki recepturowe? Wydaje się, że tak nie jest. Z pewnością obligatoryjne jest wydawanie (sprzedaż) produktów leczniczych, a zaniechanie może skutkować sankcjami administracyjnoprawnymi (zob. art. 103 ust. 2 pkt 3 p.f.). Nie budzi także wątpliwości, że sprzedaż innych produktów wymienionych w art. 75 ust. $5 \mathrm{w}$ zW. $\mathrm{z}$ art. 86 ust. 8 p.f. jest fakultatywna ${ }^{33}$.

Stanowisko drugie zakłada, że brak wspomnianego rozporządzenia nie stanowi przeszkody do dokonywania przez apteki innych, niż przewidziane w przepisach czynności związanych z ochroną zdrowia, za czym przemawia

${ }^{30}$ Zob. wyrok WSA w Warszawie z 24.02.2016 r., VI SA/Wa 1959/15, LEX nr 2055303; wyrok Wojewódzkiego Sądu Administracyjnego w Warszawie z dnia 26.03.2012, VI SA/Wa 176/12, LEX nr 1277089; por. wyrok WSA w Warszawie z dnia 14 czerwca 2010 r., VI SA/Wa 565/10.

${ }^{31}$ Wyrok NSA z 3.12.2013 r., II GSK 876/12, LEX nr 1530507.

${ }^{32}$ Wyrok WSA w Warszawie z 4.12.2007 r., LEX nr 452341.

${ }^{33}$ W.L. OlsZewsKi, Komentarz do art. 86, [w:] Prawo farmaceutyczne. Komentarz, red. W.L. Olszewski, art. 86, Nb. 17; por. wyrok WSA w Warszawie z 4.12.2007 r., VII SA/Wa 1299/07. 
konstytucyjna zasada wolności gospodarczej i konieczność wykładni przepisów ją ograniczających zgodnie z zasadą „w razie wątpliwości na korzyść" (in dubio pro liberate). Dodatkowo podnosi się, że takie czynności mieszczą się w pojęciu wykonywania zawodu farmaceuty (art. 2a ust. 1 pkt 7 u.i.a. ${ }^{34}$ ), a zatem są dopuszczalne. Przejawem tego stanowiska było dopuszczenie $\mathrm{w}$ orzecznictwie czynności w postaci wystawienia w aptece ciśnieniomierza do bezpłatnego użytku klientom apteki ${ }^{35}$. Inne czynności z tego zakresu wymieniane w piśmiennictwie to usługi nieodpłatne (art. 750 k.c.) i darowizny (art. 888 k.c.): „wykonywanie podstawowych badań diagnostycznych (pomiar masy ciała, wzrostu, ciśnienia), przyjmowanie do utylizacji przeterminowanych leków, udostępnianie materiałów edukacyjnych, nieodpłatne przekazywanie glukometrów, doradztwo żywieniowe, dermokonsultacje itp." ${ }^{36}$.

Zajmując stanowisko we wspomnianym sporze, należy zauważyć, że kluczowe w nim jest rozstrzygnięcie, czy (sporne) czynności apteki ogólnodostępnej miałyby być wykonywane w sposób stały i skoordynowany celem osiągnięcia zarobku, czy jedynie okazjonalnie i bez zarobku. Znacznie trudniej jest opowiedzieć się za dopuszczalnością pierwszej propozycji. Mogłaby ona prowadzić w konsekwencji do zmiany charakteru apteki na usługodawcę pewnych usług zarobkowych. $\mathrm{Z}$ art. 86 ust. 1-2, 5, 8-9, art. 87 ust. 2 p.f. jednoznacznie wynika, że apteka może w ograniczonym zakresie w sposób stały i skoordynowany dla zysku dokonywać tylko pewnych, określonych czynności. Jeżeli minister zdrowia nie skorzystał $\mathrm{z}$ upoważnienia ustawowego do wyznaczenia innych dozwolonych czynności aptek, to nie wolno opowiadać się za swobodą ich podejmowania. Z kolei przyjęcie drugiej propozycji wydaje się dopuszczalne, jeżeli czynności mieszczą się w pojęciu wykonywania zawodu farmaceuty (art. 2a ust. 1 pkt 7 u.i.a.). Działalność apteki ogólnodostępnej nie zasadza się wówczas na stałym i skoordynowanym podejmowaniu szeregu takich czynności w celach zarobkowych. A zatem nie dochodzi do przekroczenia ustawowych ograniczeń dotyczących działalności aptek. Wspomniane przepisy nie mogą być interpretowane przesadnie restrykcyjnie, co oznaczałoby kategoryczny zakaz podejmowania przez aptekę innych, niż wynikające wprost z przepisów czynności, w szczególności tych mieszczących się w pojęciu wykonywania zawodu farmaceuty (art. 2a ust. 1

\footnotetext{
${ }^{34}$ Ustawa z 19 kwietnia 1991 r. o izbach aptekarskich, t.j. Dz.U. z 2016 r., poz. 1496; z 2018 r., poz. 1669; z 2019 r., poz. 399, 577.

${ }^{35}$ Wyrok NSA z 11.01.2012 r., II GSK 1365/10; W.L. OlSZEWSKI, Komentarz do art. 86, Nb. 9.

${ }^{36}$ W.L. OlszewsKi, Komentarz do art. $86, \mathrm{Nb}$. 10; zob. podobnie, choć z podaniem węższego zakresu czynności J. STEFAŃCZYK-KACZMARZYK, Komentarz do art. 86, [w:] Prawo farmaceutyczne, red. M. Kondrat, art. 86, Nb. 86.2.4.
} 
pkt 7 u.i.a.), np. nieodpłatne okazyjne badania diagnostyczne, doradztwo żywieniowe, nauka prawidłowego pomiaru poziomu cukru, kontrola masy ciała. Wymienione czynności nie mogą być jednak podejmowane w celu reklamowym, który jest niedozwolony (art. 52 p.f.).

Z całą pewnością niedozwolone są czynności, które nie mieszczą się w katalogu czynności związanych $\mathrm{z}$ ochroną zdrowia i wykonywaniem zawodu farmaceuty, np. sprzedaż książek o tematyce zdrowotnej lub kart podarunkowych na zakup leków, pośredniczenie w zawieraniu umów ubezpieczeń zdrowotnych itp. ${ }^{37}$ Ich związek $\mathrm{z}$ ochroną zdrowia jest bardzo odległy. W istocie są to czynności o celach ściśle komercyjnych i tym samym sprzecznych ze statusem apteki, jako placówką ochrony zdrowia.

Punkty apteczne mogą prowadzić obrót jedynie tymi produktami leczniczymi, które są wyznaczone w rozporządzeniu Ministra Zdrowia z 22.10.2010 r. w sprawie wykazu produktów leczniczych, które mogą być dopuszczone do obrotu w placówkach obrotu pozaaptecznego oraz punktach aptecznych ${ }^{38}$. Nie mogą świadczyć wszystkich usług farmaceutycznych, np. sporządzać leków recepturowych, realizować recepty „Rp.w” - wydawanej na druku ścisłego zarachowania - na substancje psychotropowe czy środki odurzające $^{39}$. Dodatkowo wobec nich ustanowiono ograniczenie terytorialne, mogą one prowadzić działalność na terenach wiejskich, jeżeli w danej wsi nie jest prowadzona apteka ogólnodostępna (art. 70 ust. 3 p.f.). Placówki obrotu pozaaptecznego mogą prowadzić tylko obrót produktami leczniczymi wydawanymi bez przypisu lekarza i wskazanymi we wspomnianym rozporządzeniu (art. 71 ust. 1, 3 p.f.).

\subsection{Tak zwany kierunek obrotu detalicznego}

$\mathrm{Z}$ art. 68 ust. 1 , art. 86 ust. 2 w zw. z art. 65 ust. 1 p.f. nie wynika, po której stronie umowy występują przedsiębiorcy prowadzący aptekę ogólnodostępną, punkt apteczny i placówkę obrotu pozaaptecznego?

W piśmiennictwie określenie „obrót detaliczny” definiuje się w nawiązaniu do pojęcia obrotu hurtowego i wyprowadza wniosek, że polega on na bezpośrednim zaopatrywaniu ludności w produkty lecznicze. Jak stwierdził $\mathrm{SN}$, dystrybuuje on leki w kierunku do pacjenta. W przeciwnym razie mamy

\footnotetext{
Nb. 14.

${ }^{37}$ Nie wyklucza całkowicie akceptacji tego poglądu W.L. OLSZEWSKI, Komentarz do art. 86,

${ }^{38}$ Dz.U. Nr 204, poz. 1353.

${ }^{39}$ Wyrok WSA w Warszawie z 4.4.2007 r., VII SA/Wa 2215/06.
} 
do czynienia $\mathrm{z}$ obrotem hurtowym ${ }^{40}$. Zgodnie $\mathrm{z}$ art. 86a p.f. zbywanie produktów leczniczych przez aptekę ogólnodostępną lub punkt apteczny hurtowni farmaceutycznej innej aptece ogólnodostępnej lub punktowi aptecznemu jest zakazane pod rygorem wystąpienia sankcji cywilnej i administracyjnej w postaci nieważności czynności oraz cofnięcia zezwolenia na prowadzenie apteki lub punktu aptecznego (art. 86a p.f., art. $58 \S 1$ k.c., art. 103 ust. 1 pkt 2 w zw. z art. 70 ust. 4 p.f.). WSA w Warszawie w wyroku z 16 marca 2017 r. przyjął, że sprzedaż produktów leczniczych przez aptekę ogólnodostępną hurtowni farmaceutycznej stanowi udział w tzw. odwróconym łańcuchu dostaw, czyli jest nienależytym prowadzeniem apteki, a w konsekwencji uzasadnia ocenę o utracie rękojmi należytego prowadzenia apteki ogólnodostępnej, co motywuje cofnięcie zezwolenia na prowadzenie apteki ${ }^{41}$.

Niedozwolona jest z wyżej wymienionych powodów praktyka działania występujących w obrocie gospodarczym tzw. grup zakupowych. Polega ona na odsprzedawaniu leków przez członka takiej grupy, którą jest jedna apteka ogólnodostępna, innej takiej aptece będącej członkiem „grupy zakupowej”42.

Z powyższych ograniczeń wynika także, że umowy przelewu wierzytelności lub przejęcia długu dotyczące produktów leczniczych mogą być zawierane jedynie przez te podmioty, które mogą uczestniczyć w obrocie detalicznym. W przeciwnym razie będą one nieważne (art. 509, 519 k.c.).

Pojawia się jednak inne pytanie, mianowicie czy apteki mogą dokonywać wspólnie zakupów, występując jako jedna strona? Jeżeli w wyniku zakupów dochodziłoby do nabycia produktów leczniczych na współwłasność, to następnie konieczne byłoby jej zniesienie w drodze nabywania udziałów w rzeczach wspólnych. To zaś stanowiłoby niedozwolony obrót produktami leczniczymi między aptekami ogólnodostępnymi. Jednak nabycie produktów leczniczych określonych w umowie jako rzeczy oznaczonych co do gatunku skutkuje tym, że świadczenie takie jest podzielne, a zatem dzieli się na tyle odrębnych stosunków zobowiązaniowych, ilu jest kupujących (art. 379 k.c.). Nie dochodzi zatem do powstania współwłasności zakupionych produktów leczniczych i konieczności jej zniesienia. Wspólne zakupy są dopuszczalne.

$\mathrm{Z}$ art. 88 ust. 1 pkt 5 p.f. wynika, że przedsiębiorcy zajmujący się obrotem detalicznym kupują produkty lecznicze od przedsiębiorców upoważnionych

\footnotetext{
${ }^{40}$ Wyrok SN z 06.12.2017 r., SDI 93/17.

${ }^{41}$ Wyrok WSA w Warszawie, VI SA/Wa 1439/16, LEX nr 2286166.

${ }^{42}$ Wyrok Wojewódzkiego Sądu Administracyjnego w Warszawie z dnia 26.03.2012, VI SA/Wa 176/12, LEX nr 1277089; B. NowAK-CHrZĄSZCZ, Komentarz do art. 68, [w:] Prawo farmaceutyczne. Komentarz, red. W.L. Olszewski, art. 68, Nb. 11.
} 
do dokonywania obrotu hurtowego produktami leczniczymi z siedzibą na terytorium $\mathrm{RP}^{43}$. Skutkiem naruszenia tej regulacji jest wystąpienie sankcji administracyjnej i cywilnej w postaci nieważności umowy zawartej przez importera i aptekę ogólnodostępną.

$\mathrm{Na}$ tle art. 86a p.f. regulującego tzw. dopuszczalny „łańcuch dostaw” pojawiają się wątpliwości. Skoro art. 86a p.f. pomija placówki obrotu pozaaptecznego, które zajmują się obrotem produktami leczniczymi wydawanymi bez przepisu lekarza (art. 71 ust. 1 p.f.), to powstaje pytanie, czy mogą one zbywać i nabywać takie produkty między sobą? Wydaje się, że tacy przedsiębiorcy mogą dokonywać jedynie obrotu detalicznego, a nie hurtowego, dlatego przedmiotem ich przedsiębiorstwa nie może być ani taki obrót, ani jego faktyczne dokonywanie. Obrót detaliczny takimi produktami między placówkami obrotu pozaaptecznego jest możliwy, choć pozbawiony znaczenia z gospodarczego punktu widzenia.

Inaczej trzeba rozstrzygnąc kolejne zagadnienie, czy przedsiębiorca prowadzący aptekę ogólnodostępną dokonujący obrotu innymi niż lecznicze produktami z art. 72 ust. 5 p.f. ma swobodę wyboru kontrahenta i prowadzonego obrotu detalicznego lub hurtowego? Ograniczenia obrotu dotyczą tylko produktów leczniczych (zob. rozdział 5 - Obrót produktami leczniczymi). Inne produkty nie są nimi objęte, ale podlegają innym regulacjom (zob. art. 72 ust. 5 in fine p.f.). Niektóre ograniczenia wynikają jednak z potrzeby zapewnienia standardów jakościowych podczas jednoczesnego obrotu produktami leczniczymi i innymi produktami. Nie ma jednak podstaw do rozciągania wszystkich ograniczeń dotyczących obrotu produktami leczniczymi na obrót innymi produktami w szerszym zakresie, niż wynika to wprost z przepisów. Apteki ogólnodostępne mogą zatem zbywać także hurtowo inne produkty z art. 72 ust. 5 p.f. na rzecz innej apteki ogólnodostępnej, punktu aptecznego i hurtowni.

Jeżeli weźmie się pod uwagę, że produkty lecznicze są rzeczami zużywalnymi, a przedsiębiorca prowadzący aptekę ogólnodostępną itp. ma na celu osiąganie zysków, to oznacza to, iż pojęcie obrotu detalicznego sprowadza się do zawierania umów sprzedaży, czyli czynności prawnych oraz czynności faktycznych służących ich wykonaniu, zwłaszcza wydawania produktów leczniczych kupującym. Przedsiębiorcy uprawnieni występują w niej jako sprzedawcy, a pacjenci jako kupujący. Z kolei pojęcie usługi farmaceutycznej polega m.in. na umowie o dzieło i czynnościach faktycznych służących jej wykonaniu, w której przedsiębiorcy uprawnieni występują jako

\footnotetext{
${ }^{43}$ B. NowAK-ChrZĄSzCZ, Komentarz do art. 68, Nb. 11.
} 
przyjmujący zamówienie, a pacjenci jako zamawiający (zob. art. 86 ust. 2 pkt 2-3 p.f., art. 628 k.c.). Częściowo pokrywa się ono z pojęciem obrotu detalicznego, ponieważ po sporządzeniu leków recepturowych i aptecznych ich własność przechodzi na pacjenta (art. 643 k.c.).

Jeżeli sprzedającym lub przyjmującym zamówienie może być tylko przedsiębiorca prowadzący aptekę ogólnodostępną, punkt apteczny lub placówkę obrotu pozaaptecznego, to kupującym i zamawiającym jedynie pacjent, który ma na celu zaspokojenie swoich potrzeb leczniczych (zob. art. 535,627 k.c., por. art. 68 ust. 5 p.f.). Z tego wynika, że może on nabywać ograniczoną wspomnianymi potrzebami ilość produktów leczniczych. Nie może także dokonywać ich zakupu w celu dalszej odsprzedaży. Nie może on bowiem dokonywać obrotu detalicznego, występując w roli sprzedawcy. Może on być natomiast reprezentowany przez pełnomocnika lub przedstawiciela ustawowego.

Obrót detaliczny oznacza także pewien określony kierunek dostaw - od apteki ogólnodostępnej, punktu aptecznego lub placówki obrotu pozaaptecznego z siedzibą na terytorium RP w kierunku do pacjenta. Doznaje on wyjątku, mianowicie pacjent może kupić i przywieźć z zagranicy (także spoza obszaru UE) bez zgody Prezesa Urzędu na własne potrzeby produkty lecznicze w liczbie nieprzekraczającej pięciu najmniejszych opakowań, z wyłączeniem środków odurzających i psychotropowych (art. 68 ust. 5-6 p.f.). Nie chodzi tu o jednorazowy zakup i przywóz, a jego częstotliwość zależy od potrzeb leczniczych pacjenta. $Z$ treści art. 68 ust. 5 p.f. wynika, że zakup i przywóz większej liczby opakowań produktów leczniczych na własne potrzeby jest możliwy za zgodą Prezesa Urzędu. Prawo farmaceutyczne nie zna jednak szczególnej procedury udzielania takiej zgody, a zatem należy stosować kodeks postępowania administracyjnego. Wspomniany wyjątek wymaga dodania dwóch uwag. Po pierwsze - chodzi tu jednak o zakup i przywóz produktu leczniczego, który zakłada bezpośrednie, czynne i osobiste działanie z wyłączeniem jednak sprowadzenia produktu leczniczego w drodze sprzedaży wysyłkowej z zagranicy ${ }^{44}$. Po drugie - o produkty lecznicze wydawane w świetle polskiego prawa z przepisu lekarza. Oznacza to, że produkty lecznicze wydawane w Polsce bez przepisu lekarza mogą być kupowane w drodze sprzedaży wysyłkowej. Nie stanowi także obrotu detalicznego bezpośrednie zastosowanie u pacjenta produktów leczniczych oraz produktów leczniczych

${ }^{44}$ Wyrok Naczelnego Sądu Administracyjnego z 6.03.2018 r., I GSK 1277/16, LEX nr 2474134; wyrok Wojewódzkiego Sądu Administracyjnego w Szczecinie z 13.07.2016 r., I SA/Sz 616/16, LEX nr 2116059; por. wyrok WSA w Gdańsku z 1.12.2016 r., III SA/Gd 675/16, dostępny na: www.orzeczenia.nsa.gov.pl 
wchodzących w skład zestawów przeciwwstrząsowych, których potrzeba zastosowania wynika z rodzaju udzielanego świadczenia zdrowotnego (art. 68 ust. 4 p.f.).

\subsection{Zawarcie, wykonanie i niewykonanie umów składających się na obrót detaliczny}

Przedsiębiorca prowadzący aptekę ogólnodostępną, punkt obrotu aptecznego lub placówkę obrotu pozaaptecznego występuje $\mathrm{z}$ reguły $\mathrm{z}$ ofertą sprzedaży produktów leczniczych przez wystawienie ich w miejscu sprzedaży na widok publiczny (art. 543 k.c.). Pacjent ją przyjmuje. W przypadku produktów leczniczych wydawanych z przepisu lekarza przesłanką ustawową ich sprzedaży pacjentowi jest posiadanie i przekazanie recepty. Umowa sprzedaży lub umowa o dzieło takiego produktu bez recepty jest nieważna (art. 96 ust. 1,4 p.f. w zw. z art. $58 \S 1$ k.c.). Także wystąpienie innych przyczyn może stanowić przeszkodę zawarcia umowy, np. zagrożenie dla życia i zdrowia pacjenta (art. 96 ust. 5 p.f.). Treść recepty rozstrzyga o przedmiocie sprzedaży, tj. jego nazwie, postaci, dawkach, ilości i dawkowaniu (art. 96a ust. 1 pkt 4 p.f.). Oznacza to, że wolność umów jest w tym przypadku ograniczona do decyzji, czy wykupić produkt leczniczy, w jakiej aptece i po jakiej cenie oferowanej przez apteki (art. 543 k.c.).

Nieuzasadniona odmowa zawarcia umowy sprzedaży przez aptekę (art. 543 k.c.) rodzi odpowiedzialność w granicach tzw. ujemnego interesu umowy, który obejmuje koszty poniesione przez pacjenta w związku z dążeniem do zawarcia umowy i potencjalne wynikłe stąd utracone korzyści. Jeżeli jednak zachowanie takie skutkowało szkodą majątkową na osobie, np. pogorszeniem się stanu zdrowia ze względu na nieprzyjęcie leku na czas, nie można wykluczyć odpowiedzialności odszkodowawczej za bezprawne zaniechanie apteki (art. 415, art. 430 k.c. w zw. z art. 68 ust. 2a, art. 70 ust. $2 a$ p.f.).

Pojęcie ,apteka” oznacza także miejsce sprzedaży, czyli miejsce zawarcia i wykonania umowy składającej się na obrót detaliczny oraz świadczenia innych usług farmaceutycznych. Miejscem tym jest z kolei odrębny budynek lub lokal niezależnie od tego, czy stanowią one odrębne nieruchomości budynkowe lub lokalowe (art. 86 ust. 2, art. 97 p.f.). Miejsca sprzedaży punktu aptecznego i placówki obrotu pozaaptecznego są wyznaczone przez ich adresy (zob. art. 70 ust. 4 w zw. z art. 100 ust. 1 pkt 3 p.f.). Wyjątkiem od tej zasady jest wysyłkowa sprzedaż produktów leczniczych wydawanych bez przepisu lekarza, dokonywana przez apteki i punkty apteczne. Nie mogą jej dokonywać placówki obrotu pozaaptecznego (art. 68 ust. 3 p.f.). 
Umowy sprzedaży składające się na obrót detaliczny produktami detalicznymi są niezwłocznie wykonywane. Nie powstaje więc z reguły kwestia terminu wykonania zobowiązania. Wyjątkiem jest sporządzanie przez aptekę leków recepturowych, co musi nastąpić w terminie 48 godzin od złożenia recepty przez pacjenta, a w przypadku leków recepturowych ze środkiem odurzającym lub oznaczonej „wydać natychmiast” - w ciągu czterech godzin. Naruszenie tych terminów, jeżeli wynika z okoliczności, za które apteka ponosi odpowiedzialność - z reguły z niedołożenia należytej staranności, skutkuje potencjalną odpowiedzialnością odszkodowawczą za szkodę (art. 476, 477, 491 k.c.). Innym przypadkiem nienależytego wykonania zobowiązania przez aptekę jest wydanie innej (większej lub mniejszej) ilości leku, niż to wynika $z$ recepty przepisanej przez lekarza ${ }^{45}$.

\section{WNIOSKI}

Każdy aspekt obrotu detalicznego produktami leczniczymi, począwszy od pozwolenia na dopuszczenie produktu leczniczego do obrotu, wymagań jakościowych stawianych produktom leczniczym, nazwy i opakowania produktu leczniczego, a skończywszy na aptekach, czyli przedsiębiorcach uprawnionych do uczestniczenia $\mathrm{w}$ obrocie detalicznym produktami leczniczymi, katalogu czynności składającym się na obrót detaliczny czy tzw. kierunek obrotu detalicznego, jest ściśle reglamentowany przez ustawę Prawo farmaceutyczne. Pomijając jednak wspomniane ograniczenia ustawowe, sam obrót detaliczny następuje na podstawie umów cywilnoprawnych. Ma więc charakter cywilnoprawny. Taki wniosek wynika już z art. 1 p.f. wskazującego na przedmiotowy zakres ustawy. Reguluje ona zasady i tryb dopuszczania do obrotu produktów leczniczych, m.in. wymagania dotyczące jakości, skuteczności i bezpieczeństwa ich stosowania, warunki obrotu produktami leczniczymi, ale z wyłączeniem czynności cywilnoprawnych, na podstawie których wspomniany obrót następuje.

Z perspektywy obrotu detalicznego produktami leczniczymi prawo farmaceutyczne to rozbudowana regulacja ograniczająca wieloaspektowo ramy cywilnoprawnego obrotu detalicznego produktami leczniczymi, z pominięciem jednak czynności cywilnoprawnych stanowiących podstawy tego obrotu. Nie jest to jedyny cel ustawy, która reguluje także wymagania publicznoprawne

${ }^{45}$ Wyrok SN z 29.03.2012 r., I CSK 332/11, LEX nr 1214632; por. wyrok Sądu Apelacyjnego w Warszawie z dnia 14.02.2014 r., VI ACa 1000/13, LEX nr 1469448. 
pod adresem uczestników obrotu, skutki naruszeń itp. Mamy w ustawie znaczące przemieszanie częściowo różnych materii regulacyjnych, których punktem wspólnym jest generalnie produkt leczniczy. W rezultacie powstała rozbudowana regulacja, której przejrzystość, jasność, spójność pozostawia wiele do życzenia. Pod adresem ustawodawcy de lege ferenda skierować należy postulat lepszego uporządkowania regulowanej materii, zwięźlejszego formułowania przepisów, poprawnego posługiwania się językiem prawnym, nawiązywania do podstawowych konstrukcji i terminologii kodeksu cywilnego tam, gdzie jest to niezbędne.

\section{BIBLIOGRAFIA}

ŹRÓDŁA

Rozporządzenie (WE) Nr 726/2004 Parlamentu Europejskiego i Rady z 31.3.2004 r. ustanawiającego wspólnotowe procedury wydawania pozwoleń dla produktów leczniczych stosowanych u ludzi i do celów weterynaryjnych i nadzoru nad nimi oraz ustanawiającego Europejską Agencję Leków, Dz. Urz. UE L Nr 136, s. 1 ze zm.

Rozporządzenie Ministerstwa Zdrowia z 20.2.2009 r. w sprawie wymagań dotyczących oznakowania opakowań produktu leczniczego i treści ulotki, t.j. Dz.U. z 2015 r., poz. 1109.

Rozporządzenie Ministra Zdrowia z 22.10.2010 r. w sprawie wykazu produktów leczniczych, które mogą być dopuszczone do obrotu w placówkach obrotu pozaaptecznego oraz punktach aptecznych, Dz.U. Nr 204, poz. 1353.

Ustawa z 23 kwietnia 1964 r. - Kodeks cywilny, t.j. Dz.U. z 2020 r., poz. 1740, 2320.

Ustawa z 19 kwietnia 1991 r. o izbach aptekarskich, t.j. Dz.U. z 2016 r., poz. 1496; z 2018 r., poz. 1669; z 2019 r., poz. 399, 577.

Ustawa z dnia 10 kwietnia - Prawo energetyczne, t.j. Dz.U. z 2018 r., poz. 755, 650, 685, 771, 1000, 1356, 1629, 1637, 2348; z 2019 r., poz. 42, 125, 492.

Ustawa z dnia 29 października 2010 r. o rezerwach strategicznych, t.j. Dz.U. z 2017 r., poz. 1846.

Ustawa z dnia 30 czerwca 2000 r. - Prawo własności przemysłowej, t.j. Dz.U. z 2021 r., poz. 324.

Ustawa z dnia 6 marca 2018 r. - Prawo przedsiębiorców, Dz.U. z 2018 r., poz. 646.

Ustawa z dnia 6 września 2001 r. - Prawo farmaceutyczne, t.j. Dz.U. z 2020 r., poz. 944, 1493, 2112; z 2021 r., poz. 97.

Ustawa z dnia 17 listopada 1964 r. - Kodeks postępowania cywilnego, t.j. Dz.U. z 2020 r., poz. 1575, 1578, 2320; z 2021 r., poz. 11.

\section{LITERATURA}

BIADUN Dobrawa: Obrót produktami leczniczymi w świetle orzecznictwa sądowego, Warszawa: Wolters Kluwer Polska 2012.

BRzozowsKi Adam: Komentarz do art. 357, [w:] Kodeks cywilny. Komentarz do artykułów 1-44911, red. Krzysztof Pietrzykowski, t. I, Warszawa: C.H. Beck 2008, s. 940-942. 
CZACHÓRSKI Witold, BrzozowsKi Adam, SAFJAn Marek, SKowrońsKA-Bocian Elżbieta: Zobowiązania. Zarys wykładu, Warszawa: Wolters Kluwer Polska 2009.

JAGIELSKA Monika, WoJTCZYK Anna: Komentarz do art. 5, [w:] Prawo farmaceutyczne. Komentarz, red. Leszek Ogiegło, Warszawa: C.H. Beck 2018, art. 5, Nb. 1-5.

JAGIELSKA Monika, WoJTCZYK Anna: Komentarz do art. 65, [w:] Prawo farmaceutyczne. Komentarz, red. Leszek Ogiegło, Warszawa: C.H. Beck 2018, art. 65, Nb. 1-41.

Kondrat Mariusz: Komentarz do art. 2, [w:] Prawo farmaceutyczne. Komentarz, red. Mariusz Kondrat, wyd. 2, Warszawa: Wolters Kluwer Polska 2016, s. 42-141.

KreKora Magdalena: Definicje, [w:] Magdalena KreKorA, Marek ŚwIERCZYŃSKI, Elżbieta TRAPLe, Prawo farmaceutyczne, Warszawa: Wolters Kluwer Polska 2008, s. 30-36.

KRUSZYŃSKI Rafał Jerzy: Obrót produktem leczniczym w ramach rynku wewnętrznego, „Przegląd Ustawodawstwa Gospodarczego” 2010, nr 7, s. 12-26.

LONGCHAMPS DE BerIER Roman: Zobowiązania, Lwów: Księgarnia Wydaw. Gubrynowicz i Syn 1938.

ŁUPSZAK-ZAJĄC Agnieszka: Realizacja roszczenia o zawarcie umowy, Warszawa: C.H. Beck 2005.

NowAK-CHRZĄSzcz Bożena: Komentarz do art. 66, 67, [w:] Prawo farmaceutyczne. Komentarz, red. Wojciech L. Olszewski, Warszawa: Wolters Kluwer Polska 2016, art. 66, Nb. 1-10, art. 67, Nb. 1-12.

NowAK-ChrzĄSzCZ Bożena: Komentarz do art. 68, [w:] Prawo farmaceutyczne. Komentarz, red. Wojciech L. Olszewski, Warszawa: Wolters Kluwer Polska, art. 68, Nb. 1-19.

OGIEGŁo Leszek: Komentarz do art. 2, [w:] Prawo farmaceutyczne. Komentarz, red. Leszek Ogiegło, Warszawa: C.H. Beck 2018, art. 2, Nb. 1-88

OLSZEWSKI Wojciech L.: Komentarz do art. 86, [w:] Prawo farmaceutyczne. Komentarz, red. Wojciech L. Olszewski, Warszawa: Wolters Kluwer Polska 2016, art. 86, Nb. 1-20.

OżóG Marcin: System handlu produktem leczniczym i produktami pokrewnymi. Problematyka prawna, Warszawa: LexisNexis 2009.

RADWAŃSKI Zbigniew: Zobowiązania - część ogólna, Warszawa: C.H. Beck 2003.

RADWAŃSKI Zbigniew: Prawo cywilne - część ogólna, Warszawa: C.H. Beck 2003.

RoszAK Michał: Handel równoległy produktami leczniczymi w prawie unijnym. Granice swobody przepływu towarów na rynku farmaceutycznym, Warszawa: Wolters Kluwer Polska 2014.

STANKIEwICZ Rafał: Model racjonalizacji dostępu do produktu leczniczego. Zagadnienia publicznoprawne, Warszawa: C.H. Beck 2014.

STANKIEWICZ Rafał: Obrót produktami leczniczymi, [w:] Instytucje rynku farmaceutycznego, red. Rafał Stankiewicz, Warszawa: Wolters Kluwer Polska 2016, s. 347-402.

STEFAŃCZYK-KACZMARZYK Justyna: Komentarz do art. 86, [w:] Prawo farmaceutyczne, red. Mariusz Kondrat, wyd. 2, Warszawa: Wolters Kluwer Polska 2016, s. 1021-1033.

ŚWIERCZYŃSKI Marek: Obrót produktami leczniczymi oraz wymagania dotyczące podmiotów prowadzących obrót, [w:] Magdalena KREKORA, Marek ŚwIERCZYŃSKI, Elżbieta TRAPLE, Prawo farmaceutyczne, Warszawa: Wolters Kluwer Polska 2008, s. 390-451. 


\title{
OBRÓT DETALICZNY PRODUKTAMI LECZNICZYMI
}

\begin{abstract}
Streszczenie
Z obrotem detalicznym produktami leczniczymi wiąże się wystąpienie niebezpieczeństwa zagrożenia zdrowia i życia pacjentów, dlatego obrót ten podlega rozbudowanym ograniczeniom ustawowym, począwszy od pozwolenia na dopuszczenie produktu leczniczego do obrotu, wymagań jakościowych stawianych produktom leczniczym, nazwy i opakowania produktu leczniczego, a skończywszy na aptekach, czyli przedsiębiorcach uprawnionych do uczestniczenia w obrocie detalicznym produktami leczniczymi, katalogu czynności składających się na obrót detaliczny, czy tzw. kierunek obrotu detalicznego. Przywołane przykładowo ustawowe ograniczenia dotyczące detalicznego obrotu produktami leczniczymi wywołują istotne problemy interpretacyjne. Niezależnie od nich powstaje inne kluczowe pytanie, mianowicie jak daleko sięgają te ustawowe ograniczenia, czy określają one jedynie zasady i tryb dopuszczania do obrotu produktów leczniczych oraz warunki obrotu produktami leczniczymi, czy tworzą także podstawy prawne, na podstawie których obrót produktami leczniczymi dokonuje się między apteką a pacjentem.
\end{abstract}

Słowa kluczowe: produkt leczniczy; obrót produktami leczniczymi; Prawo farmaceutyczne

\section{RETAIL TRADE OF MEDICINAL PRODUCTS}

\section{S u m m a r y}

The retail trade in medicinal products is associated with the risk of a threat to the health and life of patients, therefore this trade is subject to extensive statutory restrictions, ranging from the authorization of the medicinal product to the market, quality requirements for medicinal products, name and packaging of the medicinal product, and ending with pharmacies, i.e. entrepreneurs entitled to participate in retail trade in medicinal products, the catalogue of activities that make up the retail trade, or the so-called the direction of retail trade. The above-mentioned statutory restrictions on retail trade in medicinal products raise significant problems of interpretation. Regardless of them, another key question arises, namely, how far do these statutory restrictions go, do they only define the rules and procedure for authorizing medicinal products to be marketed and the conditions for trading in medicinal products, or also create the legal basis on which medicinal products are traded between pharmacies and the patient.

Keywords: medicinal products; trade of medicinal products; the Pharmaceutical Law 